Discussion Paper No. 02-76

\title{
Entrepreneurship Capital and Economic Performance
}

David B. Audretsch and Max Keilbach

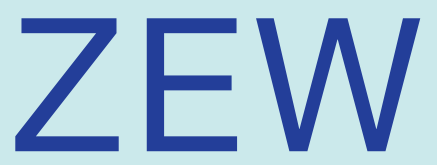

Zentrum für Europäische Wirtschaftsforschung $\mathrm{GmbH}$

Centre for European Economic Research 
Discussion Paper No. 02-76

\title{
Entrepreneurship Capital and Economic Performance
}

\author{
David B. Audretsch and Max Keilbach
}

Download this ZEW Discussion Paper from our ftp server:

\section{ftp://ftp.zew.de/pub/zew-docs/dp/dp0276.pdf}

Die Discussion Papers dienen einer möglichst schnellen Verbreitung von neueren Forschungsarbeiten des ZEW. Die Beiträge liegen in alleiniger Verantwortung der Autoren und stellen nicht notwendigerweise die Meinung des ZEW dar.

Discussion Papers are intended to make results of ZEW research promptly available to other economists in order to encourage discussion and suggestions for revisions. The authors are solely responsible for the contents which do not necessarily represent the opinion of the ZEW. 


\title{
Entrepreneurship Capital and Economic Performance
}

\author{
David B. Audretsch and Max Keilbach
}

\section{Non technical Summary}

The neoclassical model of the production function, as applied by Robert Solow to build the neoclassical model of growth, linked labor and capital to output. More recently, Romer and others have expanded the model to include measures of knowledge capital. In this paper we introduce a new factor, entrepreneurship capital, and link it to output in the context of a production function model. This paper explains what is meant by entrepreneurship capital and why it should influence economic output. Entrepreneurship capital is measured in this paper by three different approaches: regional startup intensities (startups relative to population) in all industries, startup intensities in the high-tech manufacturing industry and in ICT industries.

A production function model including several different measures of entrepreneurship capital is then estimated for German regions. The results indicate that entrepreneurship capital is a significant and important factor shaping output and productivity. These results suggest a new direction for policy that focuses on instruments to enhance entrepreneurship capital.

\section{Nicht-technische Zusammenfassung}

Robert Solow gründete seine Wachstumstheorie auf das neoklassische Produktionsmodell, das Output als Resultat der Kombination von Kapital und Arbeit spezifiziert. Dieser Ansatz wurde in der jüngeren Vergangenheit von Paul Romer und anderen um den Faktor Humankapital bzw. um einen FuE-Sektor erweitert. Mit diesem Aufsatz stellen wir die Bedeutung eines weiteren Produktionsfaktors heraus: Entrepreneurship Kapital. Vereinfacht gesprochen ist hierunter die Fähigkeit von Wirtschaftssubjekten zu verstehen, neue Firmen zu gründen. Wir messen diese Variable mittels mehrer Proxies: Gründungsintensität (Gründungen relativ zur Bevölkerung) in allen Wirtschaftszweigen, Gründungen in den Hochtechnologiebranchen des verarbeitenden Gewerbes und in den IKT Branchen.

Wir spezifizieren ein neoklassisches Produktionsmodell unter sukzessivem Einschluss der Variablen Kapital, Arbeit, FuE-Personal und Entrepreneurship Kapital. Eine Abwandlung des Modells schätzt den Einfluss dieser Variablen auf die Arbeitsproduktivität. Bei den Schätzungen verwenden wir Beobachtungen auf Kreisebene für das Verarbeitende Gewerbe Westdeutschlands. Die Schätzergebnisse stützen die Hypothese, dass Entrepreneurship Kapital einen positiven und signifikanten Einfluss auf den regionalen Output und die regionale Arbeitsproduktivität haben. Dies legt nahe, dass eine wirtschaftspolitische Förderung der Schaffung von Entrepreneurship Kapital ceteris paribus die wirtschaftliche Performance der Zielsubjekte (Regionen oder Branchen) erhöhen könnte. 


\title{
Entrepreneurship Capital and Economic Performance ${ }^{1}$
}

\author{
David B. Audretsch ${ }^{2}$ and Max Keilbach ${ }^{3}$
}

\begin{abstract}
The neoclassical model of the production function, as applied by Robert Solow to build the neoclassical model of growth, linked labor and capital to output. More recently, Romer and others have expanded the model to include measures of knowledge capital. In this paper we introduce a new factor, entrepreneurship capital, and link it to output in the context of a production function model. This paper explains what is meant by entrepreneurship capital and why it should influence economic output. A production function model including several different measures of entrepreneurship capital is then estimated for German regions. The results indicate that entrepreneurship capital is a significant and important factor shaping output and productivity. These results suggest a new direction for policy that focuses on instruments to enhance entrepreneurship capital.
\end{abstract}

Keywords: Production Function, Entrepreneurship Capital, Regional Economic Performance

JEL-Codes: M13, O32, O47

\footnotetext{
${ }^{1}$ We gratefully acknowledge financial support by the Deutsche Forschungsgemeinschaft (DFG) within research focus "Interdisziplinäre Gründungsforschung" under contract number STA 169/10-1

${ }^{2}$ Indiana University, CEPR and Research Professor at the Centre for European Economic Research (ZEW), Mannheim

${ }^{3}$ Centre for European Economic Research (ZEW), Mannheim
} 
The Entrepreneur is the single most important player in a modern economy

Edward Lazear (2002, p.1)

\section{Introduction}

Ever since Robert Solow (1956) based his model of economic growth on the neoclassical production function with its key factors of production, capital and labor, economists have relied upon the model of the production function as a basis for explaining the determinants of economic growth. Romer's (1986) critique of the Solow approach was not with the basic model of the neoclassical production function, but rather what he perceived to be omitted from that model - knowledge. Not only did Romer (1986), along with Lucas (1988) and others argue that knowledge was an important factor of production, along with the traditional factors of labor and capital, but because it was endogenously determined as a result of externalities and spillovers, it was particularly important.

The purpose of this paper is to suggest that another key factor has been omitted from the neoclassical production function - entrepreneurship capital. By entrepreneurship capital we mean the capacity for economic agents to generate new firms. As Gartner and Carter (2003) state, "Entrepreneurial behavior involves the activities of individuals who are associated with creating new organizations rather than the activities of individuals who are involved with maintaining or changing the operations of on-going established organizations."

Entrepreneurship has typically been referred to as an action, process, or activity. We propose that it can also be considered to constitute a stock of capital, since it reflects a number of different factors and forces, legal, institutional and social, that create a capacity for this activity (Hofstede et. al., 2002). A recent literature has emerged suggesting that entrepreneurship capital may be something of a missing link in explaining variations in economic performance (Acs and Audretsch, 2003). However, while a rich literature has emerged identifying the determinants of entrepreneurship, led by the pioneering study of Evans and Leighton (1989), the link between entrepreneurship capital and performance remains largely ancedotal or based on case studies. For example, Saxenian (1994) provides compelling case study evidence attributing the superior performance of Silicon Valley to a high capacity for promoting entrepreneurship, which could be viewed as a rich endowment of entrepreneurship capital.

Baumol (2002, pp. 58-59) has argued that entrepreneurial activity may account for a significant amount of the growth left unexplained in traditional production function models. While the traditional factors of labor and capital, and even the addition of knowledge capital are important in shaping output, the capacity to harness new ideas by creating new enterprises is also essential to economic output. A counter-example is instructive. In the former Soviet Union, while the exact measures of the stocks of capital and labor, and even knowledge, were questionable, their existence was not. By contrast, entrepreneurship capital, at least as it could be legally applied, was minimal.

The second section of this paper is devoted to defining entrepreneurship capital, and explaining why is should be linked to output in the context of a production function model. In the third section we specify the production function to be estimated and expose the data. A production function model is estimated for German regions in the fourth section. The final section provides a summary and conclusion. In particular, the evidence suggests that various measures of entrepreneurship capital do, in fact, contribute to output. Those regions with a higher level of entrepreneurship capital exhibit higher levels of output and productivity, while those with a paucity of entrepreneurship capital tend to generate lower levels of output and productivity. 


\section{Entrepreneurship Capital}

While it has become widely acknowledged that entrepreneurship is a vital force in the economies of developed countries, there is little consensus about what actually constitutes entrepreneurial activity. Scholars have proposed a broad array of definitions, which when operationalized, have generated a number of different measures (Hebert and Link, 1989). Similarly, there is no generally accepted definition of entrepreneurship for the developed countries of the OECD (OECD, 1998). The failure of a single definition of entrepreneurship to emerge undoubtedly reflects the fact that it is a multidimensional concept. The actual definition used to study or classify entrepreneurial activities reflects a particular perspective or emphasis. For example, definitions of entrepreneurship typically vary between the economic and management perspectives. From the economic perspective, Hebert and Link (1989) distinguish between the supply of financial capital, innovation, allocation of resources among alternative uses and decision-making. Thus, an entrepreneur is someone encompassing the entire spectrum of these functions: "The entrepreneur is someone who specializes in taking responsibility for and making judgmental decisions that affect the location, form, and the use of goods, resources or institutions" (Hebert and Link, 1989, p. 213).

The most prevalent and compelling views of entrepreneurship focus on the perception of new economic opportunities and the subsequent introduction of new ideas in the market. Just as entrepreneurs are agents of change; entrepreneurship is thus about the process of change. This corresponds to the definition of entrepreneurship proposed by the OECD, "Entrepreneurs are agents of change and growth in a market economy and they can act to accelerate the generation, dissemination and application of innovative ideas... Entrepreneurs not only seek out and identify potentially profitable economic opportunities but are also willing to take risks to see if their hunches are right" (OECD, 1998, p. 11).

While the entrepreneur undertakes a definitive action, starting a new business, her action cannot be viewed in a vacuum devoid of context. Rather, as Audretsch et al. (2002) show, the determinants of entrepreneurship are shaped by a number of forces and factors, including legal and institutional but also social factors as well. The study of social capital and its impact on economic decision making and actions stems back to classic literatures in economics and sociology in which social and relational structure influence market processes (Granovetter 1985). Thorton and Flynne (2003) and Saxenian (1994) attribute the high economic performance of Silicon Valley to a rich endowment of what could be termed as entrepreneurship capital," It is not simply the concentration of skilled labor, suppliers and information that distinguish the region. A variety of regional institutions - including Stanford University, several trade associations and local business organizations, and a myriad of specialized consulting, market research, public relations and venture capital firms - provide technical, financial, and networking services which the region's enterprises often cannot afford individually. These networks defy sectoral barriers: individuals move easily from semiconductor to disk drive firms or from computer to network makers. They move from established firms to startups (or vice versa) and even to market research or consulting firms, and from consulting firms back into startups. And they continue to meet at trade shows, industry conferences, and the scores of seminars, talks, and social activities organized by local business organizations and trade associations. In these forums, relationships are easily formed and maintained, technical and market information is exchanged, business contacts are established, and new enterprises are conceived...This decentralized and fluid environment also promotes the diffusion of intangible technological capabilities and understandings"1 (Saxenian, 1990, pp. 96-97).

\footnotetext{
${ }^{1}$ Saxenian (1990, pp. 97-98) claims that even the language and vocabulary used by technical specialists can be specific to a region: ".... a distinct language has evolved in the region and certain technical terms used by semi-
} 
Such contexts generating a high propensity for economic agents to start new firms can be characterized as being rich in entrepreneurship capital. Other contexts, where the startup of new firms is inhibited, can be characterized as being weak in entrepreneurship capital.

Entrepreneurship capital exerts a positive impact on economic output for a number of reasons. The first is that it is a mechanism for knowledge spillovers. Romer (1986), Lucas (1988 and 1992) and Grossman and Helpman (1991) established that knowledge spillovers are an important mechanism underlying endogenous growth. However, they shed little light on the actual mechanisms by which knowledge is transmitted across firms and individuals. The answer to this question is important, because a policy implication commonly drawn from the new economic growth theory is that, as a result of convexities in knowledge and the resultant increasing returns, knowledge factors, such as R\&D should be publicly supported. While this may be valid, it is also important to recognize that the mechanisms for spillover transmission may also play a key role and may also serve as a focus for public policy enhancing economic growth and development.

The literature identifying mechanisms actually transmitting knowledge spillovers is sparse and remains underdeveloped. However, one important area where such transmission mechanisms have been identified involves entrepreneurship. Entrepreneurship involves the startup and growth of new enterprises.

Why should entrepreneurship serve as a mechanism for the spill over of knowledge from the source of origin? At least two major channels or mechanisms for knowledge spillovers have been identified in the literature. Both of these spillover mechanisms revolve around the issue of appropriability of new knowledge. Cohen and Levinthal (1989) suggest that firms develop the capacity to adapt new technology and ideas developed in other firms and are therefore able to appropriate some of the returns accruing to investments in new knowledge made externally. This view of spillovers is consistent with the traditional model of the knowledge production function, where the firm exists exogenously and then undertakes (knowledge) investments to generate innovative output.

By contrast, Audretsch (1995) proposes shifting the unit of observation away from exogenously assumed firms to individuals, such as scientists, engineers or other knowledge workers - agents with endowments of new economic knowledge. When the lens is shifted away from the firm to the individual as the relevant unit of observation, the appropriability issue remains, but the question becomes, How can economic agents with a given endowment of new knowledge best appropriate the returns from that knowledge? If the scientist or engineer can pursue the new idea within the organisational structure of the firm developing the knowledge and appropriate roughly the expected value of that knowledge, he has no reason to leave the firm. On the other hand, if he places a greater value on his ideas than do the decision-making bureaucracy of the incumbent firm, he may choose to start a new firm to appropriate the value of his knowledge. Small enterprises can compensate for their lack of R\&D through spillovers and spin-offs. Typically an employee from an established large corporation, often a scientist or engineer working in a research laboratory, will have an idea for an invention and ultimately for an innovation. Accompanying this potential innovation is an expected net return from the new product. The inventor would expect to be compensated for his/her potential innovation accordingly. If the company has a different, presumably lower, valuation of the potential innovation, it may decide either not to pursue its development, or that it merits a lower level of compensation than that expected by the employee.

In either case, the employee will weigh the alternative of starting his/her own firm. If the gap in the expected return accruing from the potential innovation between the inventor and the corporate decision maker is sufficiently large, and if the cost of starting a new firm is

conductor production engineers in Silicon Valley would not even be understood by their counterparts in Boston's Route 128." 
sufficiently low, the employee may decide to leave the large corporation and establish a new enterprise. Since the knowledge was generated in the established corporation, the new start-up is considered to be a spin-off from the existing firm. Such start-ups typically do not have direct access to a large R\&D laboratory. Rather, these small firms succeed in exploiting the knowledge and experience accrued from the R\&D laboratories with their previous employers. The research laboratories of universities provide a source of innovation-generating knowledge that is available to private enterprises for commercial exploitation. Jaffe (1989) and Audretsch and Feldman (1996) found that the knowledge created in university laboratories "spills over" to contribute to the generation of commercial innovations by private enterprises. Acs, Audretsch, and Feldman (1994) found persuasive evidence that spillovers from university research contribute more to the innovative activity of small firms than to the innovative activity of large corporations.

In the metaphor provided by Albert O. Hirschman (1970), if voice proves to be ineffective within incumbent organizations, and loyalty is sufficiently weak, a knowledge worker may resort to exit the firm or university where the knowledge was created in order to form a new company. In this spillover channel the knowledge production function is actually reversed. The knowledge is exogenous and embodied in a worker. The firm is created endogenously in the worker's effort to appropriate the value of his knowledge through innovative activity. Thus, entrepreneurhip serves as the mechanism by which knowledge spills over from the source creating to a new firm where it is commercialized.

A second way that entrepreneurship capital exerts a positive influence on economic output is through the increased competition by the increased number of enterprises. Jacobs (1969) and Porter (1990) argue that competition is more conducive to knowledge externalities than is local monopoly. It should be emphasised that by local competition Jacobs does not mean competition within product markets as has traditionally been envisioned within the industrial organisation literature. Rather, Jacobs is referring to the competition for the new ideas embodied in economic agents. Not only does an increased number of firms provide greater competition for new ideas, but in addition, greater competition across firms facilitates the entry of a new firm specializing in some particular new product niche. This is because the necessary complementary inputs and services are likely to be available from small specialist niche firms but not necessarily from large, vertically integrated producers.

Both Feldman and Audretsch (1999) as well as Glaeser, Kallal, Sheinkman and Schleifer (1992) found empirical evidence supporting the hypothesis that an increase in competition, as measured by the number of enterprises, in a city increases the growth performance of that city.

A third way that entrepreneurship capital generates economic output is by providing diversity among the firms. Not only does entrepreneurship capital generate a greater number of enterprises, but it also increases the variety of enterprises in the location. A key assumption made by Hannan and Freeman (1989) in the population ecology literature is that each new organization represents a unique approach. There has been a series of theoretical arguments suggesting that the degree of diversity, as opposed to homogeneity, in a location will influence the growth potential.

The theoretical basis linking diversity to economic performance is provided by Jacobs (1969), who argues that the most important source of knowledge spillovers are external to the industry in which the firm operates and that cities are the source of considerable innovation because the diversity of these knowledge sources is greatest in cities. According to Jacobs, it is the exchange of complementary knowledge across diverse firms and economic agents which yields a greater return on new economic knowledge. She develops a theory that emphasizes that the variety of industries within a geographic region promotes knowledge externalities and ultimately innovative activity and economic growth. 
The first important test linking diversity to economic performance, measured in terms of employment growth was by Glaeser, Kallal, Sheinkman and Schleifer (1992), who employ a data set on the growth of large industries in 170 cities between 1956 and 1987 in order to identify the relative importance of the degree of regional specialization, diversity and local competition play in influencing industry growth rates. The authors find evidence that diversity promotes growth in cities.

Feldman and Audretsch (1999) identified the extent to which the extent of diversity influences innovative output. They link the innovative output of product categories within a specific city to the extent to which the economic activity of that city is concentrated in that industry, or conversely, diversified in terms of complementary industries sharing a common science base.

Entrepreneurship capital therefore can contribute to output and growth by serving as a conduit for knowledge spillovers, increasing competition, and by injecting diversity. Inclusion of measures of entrepreneurship capital would be expected to be positively related to output.

\section{Production Function Model and Measurement Issues}

The goal of this paper is include a measure of entrepreneurship capital in estimating a production function model for German regions. Using a specification of the Cobb-Douglas type we obtain

$$
Y_{i}=\alpha K_{i}^{\beta_{1}} L_{i}^{\beta_{2}} R_{i}^{\beta_{3}} E_{i}^{\beta_{4}} e^{\varepsilon_{i}}
$$

where K represents the factor of physical capital, L represents labor, $\mathrm{R}$ represents knowledge capital, and E represents entrepreneurship capital. The subscript $i$ refers to German regions.

Measurement of entrepreneurship capital is no less complicated than is measuring the traditional factors of production. Just as measuring capital, labor and knowledge invokes numerous assumptions and simplifications, creating a metric for entrepreneurship capital presents a challenge. Many of the elements determining entrepreneurship capital defy quantification. In any case, entrepreneurship capital, like all of the other types of capital, is multifaceted and heterogeneous. However, entrepreneurship capital manifests itself in a singular way - the startup of new enterprises. Thus, we propose using new-firm startup rates as an indicator of entrepreneurship capital. Ceteris paribus, higher startup rates reflect higher levels of entrepreneurship capital. Our data will consist in a cross-section of 327 West-German regions or Kreise for the year 1992 if not indicated otherwise. Sources and construction of the data is as follows.

Output is measured as Gross Value Added corrected for purchases of goods and services, VAT and shipping costs. Statistics are published every two years for Kreise by the Working Group of the Statistical Offices of the German Länder, under "Volkswirtschaftiche Gesamtrechnungen der Länder"'.

Physical Capital: The stock of capital used in the manufacturing sector of the Kreise has been estimated using a perpetual inventory method which computes the stock of capital as a weighted sum of past investments. In the estimates we used a -distribution with $p=9$ and a mean age of $q=14$. Type of survival function as well as these parameters have been provided by the German Federal Statistical Office in Wiesbaden. This way, we attempted to obtain maximum coherence with the estimates of the capital stock of the German producing sector as a whole as published by the Federal Statistical Office. Data on investment at the level of German Kreise is published annually by the Federal 
Statistical Office in the series "E I 6". These figures however are limited to firms of the producing sector, excluding the mining industry, with more than 20 employees. The vector of the producing sector as a whole has been estimated by multiplying these values such that the value of the capital stock of Western Germany - as published in the Statistical Yearbook - was attained. Note that this procedure implies that estimates for Kreise with a high proportion of mining might be biased. Note also that for protection purposes, some Kreise did not publish data on investment (like e.g. the city of Wolfsburg, whose producing sector is dominated by Volkswagen). Therefore five Kreise are treated as missing.

Labor: Data on labor is published by the Federal Labor Office, Nürnberg which reports number of employees liable to social insurance by Kreise.

Knowledge Capital is expressed as number of employees engaged in $R \& D$ in the public (1992) and in the private sector (1991). With this approach we follow the examples of of Griliches (1979), Jaffe (1989), and Audretsch and Feldman (1996). Data have been communicated by the Stifterverband für die Wissenschaft under obligation of secrecy. With these data, it was impossible to make a distinction between R\&D-employees in the producing and non-producing sectors. Regression results therefore will implicitly include spillovers from R\&D of the non-producing sector to the producing sectors. We presume however that this effect is rather low.

Entrepreneurship Capital is computed as the number of startups in the respective region relative to its population, which reflects the propensity of inhabitants of a region to start a new firm The data on startups is taken from the ZEW foundation panels that is based on data provided biannually by Creditreform, the largest German credit-rating agency. This data contains virtually all entries - hence startups - in the German Trade Register, especially for firms with large credit requirements as e.g. high-technology firms. ${ }^{2}$ By now, there are 1.6 million entries for Western-Germany. Since number of startups is subject to a greater level of stochastic disturbance over short time periods, it is prudent to compute the measure of entrepreneurship capital based on startup rates over a longer time period. We therefore used the number of startups between 1989-1992. Lagged values of start-up rates are used in order to avoid problems of simultaneity between output and entrepreneurship. This lagged relationship reflects causality between entrepreneurship capital in one period and economic output in subsequent periods. While we argue in this paper that entrepreneurship capital should include startup activity in any industry, some scholars have suggested that it should only apply to startups involving innovative activity. Therefore, we compute two modified measures of entrepreneurship. The first one restricts entrepreneurship capital to include only startup activity in high-technology manufacturing industries (whose R\&D-intensity is above $2.5 \%$ ). The second measure restricts entrepreneurship capital to include only startup activity in the ICT industries, i.e. firms in the hard- and software business. Some of these industries are also classified under high-technology manufacturing.

\footnotetext{
${ }^{2}$ Firms with low credit requirements, with a low number of employees or with illimited legal forms are registered only with a time lag. These are typically retail stores or catering firms. See Harhoff and Steil (1997) for more detail on the ZEW foundation panels.
} 
Table 1: Regions ranked by startup intensity (startups 1989 - 1992 per population) of all industries

\begin{tabular}{llr} 
Rank & Region & Startup Intensity \\
\hline 1 & München, surrounding area & 24,634561 \\
2 & Düsseldorf, city & 20,241409 \\
3 & Hamburg, city & 19,669706 \\
4 & Offenbach, surrounding area & 18,606913 \\
5 & Wiesbaden, city & 17,671311 \\
6 & Starnberg & 17,101142 \\
7 & München, city & 16,081293 \\
8 & Frankfurt a.M., city & 15,956175 \\
9 & Hochtaunuskreis & 15,866653 \\
10 & Speyer, city & 15,395183 \\
\hline 11 & Passau, city & 15,254072 \\
12 & Freising & 14,850592 \\
13 & Memmingen, city & 14,805079 \\
14 & Landsberg a. Lech & 14,792960 \\
15 & Offenbach a. M., city & 14,620285 \\
16 & Segeberg & 14,572237 \\
17 & Diepholz & 14,435722 \\
18 & Main-Taunus-Kreis & 14,232831 \\
19 & Ebersberg & 13,811470 \\
20 & Dachau & 13,779904 \\
\hline$\ldots$ & & \\
308 & Wesermarsch & 6,006103 \\
309 & Wolfsburg, city & 6,001654 \\
310 & Cham & 5,991514 \\
311 & Sankt Wendel & 5,919445 \\
312 & Neckar-Odenwald-Kreis & 5,912736 \\
313 & Donnersbergkreis & 5,896884 \\
314 & Schweinfurt & 5,896509 \\
315 & Emsland & 5,774027 \\
316 & Uelzen & 5,758620 \\
317 & Salzgitter, city & 5,668607 \\
\hline 318 & Lichtenfels & 5,551670 \\
319 & Trier-Saarburg & 5,541770 \\
320 & Herne, city & 5,526887 \\
321 & Grafschaft Bentheim & 5,428270 \\
322 & Höxter & 5,287556 \\
323 & Bremerhaven, city & 5,258049 \\
324 & Tirschenreuth & 5,198918 \\
325 & Coburg & 5,193940 \\
326 & Cuxhaven & \\
327 & Kusel & \\
\hline & & \\
\hline 3 & &
\end{tabular}




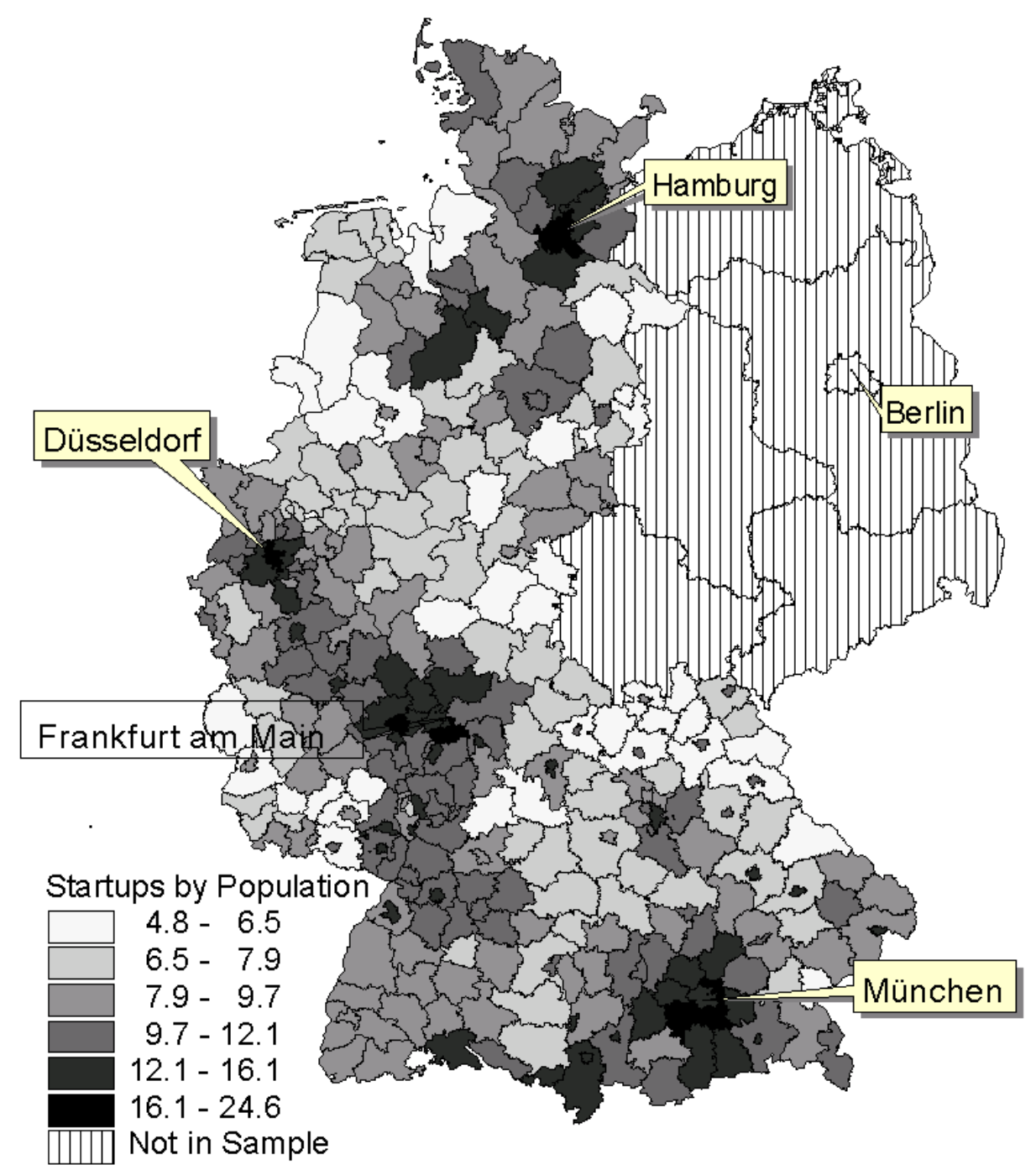

Figure 1: Spatial distribution of Entrepreneurship Capital measured as the number of startups in all industries relative to population in each region.

The spatial distribution of the measure of Entrepreneurship capital based on all industries is shown in Figure 1. As Table 1 makes clear, the regions exhibiting the highest amounts of Entrepreneurship Capital are Munich, Düsseldorf, and Hamburg. By contrast, the regions with the lowest amount of Entrepreneurship Capital are Kusel, Cuxhaven and Coburg. This ranking will differ slightly, though not fundamentally if we use startups in high-tech manufacturing industries or in ICT industries instead of startups in all industries. This is indicated by the positive and significant correlation between all three measures of entrepreneurship shown in Table 2. Table 5 and Table 6 (page 14) show the ranking of regions (showing again the 20 strongest and the 20 weakest regions) when using the two alternative measures of entrepreneurship capital. 
Table 2: Correlation between different measures of entrepreneurship capital and between these measures and population density for 327 German Kreise

\begin{tabular}{|l|l|l|l|}
\cline { 2 - 4 } \multicolumn{1}{c|}{} & $\begin{array}{l}\text { Population } \\
\text { Density }\end{array}$ & $\begin{array}{l}\text { Startups in all } \\
\text { industries }\end{array}$ & $\begin{array}{l}\text { High-tech manuf. } \\
\text { startups }\end{array}$ \\
\hline Startups in all ind. & $0.338^{* * *}$ & & \\
\hline High-tech startups & 0.028 & $0.510^{* * *}$ & \\
\hline ICT startups & $0.287^{* * *}$ & $0.816^{* * *}$ & $0.612^{* * *}$ \\
\hline
\end{tabular}

Note: *** correlation is significant at $1 \%$ based on a two sided t-test

\section{Empirical Results}

Estimation of the production function model of Equation 1 produced the results displayed in Table 3. The first equation estimates the traditional Solow model of the production function. As the positive and statistically significant coefficients suggest, both physical capital and labor are important factors of production in determining output in German regions. In the second column the factor of knowledge capital is added. The positive and statistically significant coefficients of all three variables lend support to the Romer view that knowledge matters as a factor of production.

Table 3: Results of Estimation of the Production Function Model for German Regions

\begin{tabular}{|c|c|c|c|c|c|}
\hline & (1) & (2) & (3) & (4) & (5) \\
\hline Constant & $\begin{array}{c}-2.755 * * * \\
(-10.749)\end{array}$ & $\begin{array}{c}-2.305 * * * \\
(-7.807)\end{array}$ & $\begin{array}{c}-1.822 * * * \\
(-4.866)\end{array}$ & $\begin{array}{c}-1.810 * * * \\
(-4.363)\end{array}$ & $\begin{array}{c}-1.474 * * * \\
(-3.804)\end{array}$ \\
\hline Capital & $\begin{array}{c}0.270 * * * \\
(5.312)\end{array}$ & $\begin{array}{c}0.279 * * * \\
(5.366)\end{array}$ & $\begin{array}{c}0.276 * * * \\
(5.333)\end{array}$ & $\begin{array}{c}0.294 * * * \\
(5.587)\end{array}$ & $\begin{array}{c}0.287 * * * \\
(5.603)\end{array}$ \\
\hline Labor & $\begin{array}{c}0.805 * * * \\
(13.241)\end{array}$ & $\begin{array}{c}0.736 * * * \\
(11.410)\end{array}$ & $\begin{array}{c}0.748 * * * \\
(11.606)\end{array}$ & $\begin{array}{c}0.715 * * * \\
\quad(10.897)\end{array}$ & $\begin{array}{c}0.734 * * * \\
(11.554)\end{array}$ \\
\hline Knowledge & & $\begin{array}{c}0.030 * * \\
(2.199)\end{array}$ & $\begin{array}{l}0.022 \\
(1.540)\end{array}$ & $\begin{array}{c}0.027 * * \\
(1.987)\end{array}$ & $\begin{array}{l}0.014 \\
(0.954)\end{array}$ \\
\hline Entrepreneurship & & & $\begin{array}{c}0.112 * * \\
(2.078)\end{array}$ & & \\
\hline $\begin{array}{l}\text { High-Tech } \\
\text { Entrepreneurship }\end{array}$ & & & & $\begin{array}{l}0.043^{*} \\
(1.694)\end{array}$ & \\
\hline $\begin{array}{l}\text { ICT } \\
\text { Entrepreneurship }\end{array}$ & & & & & $\begin{array}{c}0.104 * * * \\
(3.244)\end{array}$ \\
\hline$R 2$ & 0.911 & 0.908 & 0.910 & 0.909 & 0.911 \\
\hline
\end{tabular}

Notes: $\quad$-statistic in brackets.

* Statistically significant at the two-tailed test for $90 \%$ level of confidence

** Statistically significant at the two-tailed test for $95 \%$ level of confidence

*** Statistically significant at the two-tailed test for $99 \%$ level of confidence 
The third column shows the results when entrepreneurship capital is also included in the production function model (1). The positive and statistically significant coefficient indicates that entrepreneurship is a key factor in explaining variations in output across German regions. Those regions with a greater degree of entrepreneurship capital exhibit higher levels of output, ceteris paribus. Columns (4) and (5) show the results for equation (1) if we use startup rates in high-tech manufacturing or in ICT industries instead of startup rates of all industries. The results indicate that using these two alternative measures of entrepreneurship capital still generates a positive and statistically significant coefficient, suggesting that entrepreneurship capital is an important addition to the model of the production function.

An alternative specification estimates labor productivity. This is obtained by dividing both sides of Equation (1) by L. In this equation, we also restrict the production elasticities of capital and labor to sum to unity, hence in terms of equation (1) we have $\beta_{1}+\beta_{2}=1$. Hence we obtain

$$
\left(Y_{i} / K_{i}\right)=\alpha\left(K_{i} / L_{i}\right)^{\gamma_{1}} R_{i}^{\gamma_{2}} E_{i}^{\gamma_{3}} e^{\varepsilon_{i}}
$$

The results for estimating labor productivity in Equation (2) are presented in Table 4. As the positive and statistically significant coefficients indicate, not only do labor, capital intensity and knowledge influence labor productivity, but entrepreneurship capital does as well. Those regions with a greater degree of entrepreneurship capital exhibit systematically higher levels of labor productivity than do those regions with lower endowments of entrepreneurship capital. These results prove to be robust for the two alternative measures of entrepreneurship capital, which are restricted to high technology and ITC industries.

Table 4: Results of Estimation of the Model of Labor Productivity in German Regions

\begin{tabular}{|c|c|c|c|c|c|}
\hline & (1) & (2) & (3) & (4) & (5) \\
\hline Constant & $\begin{array}{c}1.888 * * * \\
(-19.235)\end{array}$ & $\begin{array}{c}-2.175 * * * \\
(-16.683)\end{array}$ & $\begin{array}{c}-1.645 * * * \\
(-5.566)\end{array}$ & $\begin{array}{c}-1.730 * * * \\
(-6.060)\end{array}$ & $\begin{array}{c}-1.299 * * * \\
(-6.060)\end{array}$ \\
\hline Capital Intensity & $\begin{array}{c}0.332 * * * \\
(6.814)\end{array}$ & $\begin{array}{c}0.283 * * * \\
(5.535)\end{array}$ & $\begin{array}{c}0.283 * * * \\
(5.551)\end{array}$ & $\begin{array}{c}0.296 * * * \\
(5.747)\end{array}$ & $\begin{array}{c}0.293 * * * \\
(5.807)\end{array}$ \\
\hline Knowledge & & $\begin{array}{c}0.035 * * * \\
(3.673)\end{array}$ & $\begin{array}{c}0.030 * * * \\
(3.028)\end{array}$ & $\begin{array}{c}0.030 * * * \\
(3.005)\end{array}$ & $\begin{array}{c}0.021 * * \\
(2.032)\end{array}$ \\
\hline Entrepreneurship & & & $\begin{array}{c}0.107 * * \\
(1.993)\end{array}$ & & \\
\hline $\begin{array}{l}\text { High-Tech } \\
\text { Entrepreneurship }\end{array}$ & & & & $\begin{array}{c}0.044^{*} \\
(1.747)\end{array}$ & \\
\hline $\begin{array}{l}\text { ICT } \\
\text { Entrepreneurship }\end{array}$ & & & & & $\begin{array}{c}0.102 * * * \\
(3.203)\end{array}$ \\
\hline$R 2$ & 0.125 & 0.169 & 0.179 & 0.177 & 0.195 \\
\hline
\end{tabular}




\section{Conclusions}

Subsequent to publication of Solow's seminal article depicting the neoclassical model of the production function as a basis for analyzing economic growth, a series of new policy directions were developed at enhancing the two traditional factors of production, physical capital and labor. Similarly, endogenous growth theory has triggered a new policy direction focusing on enhancing knowledge capital through investments in R\&D, education, and human capital. The results of this paper suggest, that at least in the case of Germany, a different and new policy direction - the enhancement of entrepreneurship capital. While these findings certainly do not contradict the conclusions of earlier studies linking growth to factors such as labor, capital, and knowledge, the evidence from this paper points to an additional factor, entrepreneurship capital, that also plays an important role in the model of the production function. It may be that, under certain conditions, policies focusing on enhancing entrepreneurship capital can prove to be more effective than those targeting the more traditional factors. In any case, future research research needs to map out more precisely the exact links and channels that policy can influence and augment entrepreneurship in such a way as to raise productivity and growth, as suggested by the results of this paper. 


\section{References}

Acs, Zoltan J. and David B. Audretsch, 2003, The International Handbook of Entrepreneurship, Dordrecht: Kluwer Academic Publishers

Acs, Zoltan J, David B. Audretsch and Maryann P. Feldmann, 1994, "R\&D Spillovers and Recipient Firm Size", Review of Economic and Statistics, 76(2), 336-340

Aldrich, Howard E. and Martha Martinez, 2003, “Entrepreneurship as Social Construction,” in Zoltan J. Acs and David B. Audretsch (eds.), The International Handbook of Entrepreneurship, Dordrecht: Kluwer Academic Publishers.

Arrow, Kenneth J., 1962, "Economic Welfare and the Allocation of Resources for Invention," in R.R. Nelson (ed.), The Rate and Direction of Inventive Activity, Princeton, NJ: Princeton University Press, pp. 609626.

Audretsch, David B. and Maryann P. Feldman , 1996, "R\&D Spillovers and the Geography of Innovation and Production," American Economic Review, 86(3), June, 630-640.

Audretsch, David B., Roy Thurik, Ingrid Verheul and Sander Wennekers, 2002, Entrepreneurship: Determinants and Policy in a European-U.S. Comparison, Boston: Kluwer Academic Publishers.

Baumol, William, J., 2002, Free Market Innovation Machine: Analyzing the Growth Miracle of Capitalism. Princeton University Press.

Cohen, W. and Levinthal, D., 1989, 'Innovation and Learning: The Two Faces of R\&D,” Economic Journal, 99(3), 569-596.

Feldmann, Maryann P. and David B. Audretsch, 1999, Innovation in Cities: Science Based Diversity, specialization and Localized Competition. European Economic Review, 43, 409-429

Gartner, William B. and Nancy M. Carter, 2003, "Entrepreneurship Behavior: Firm Organizing Processes," in Zoltan J. Acs and David B. Audretsch (eds.), The International Handbook of Entrepreneurship, Dordrecht: Kluwer Academic Publishers.

Glaeser, E., Kallal, H., Scheinkman, J. and Shleifer, A., 1992, “Growth of Cities,” Journal of Political Economy, 100, 1126-1152.

Granovetter, Mark S., 1983, “The Strength of Weak Ties: A Network Theory Revisited,” In Randall Collins (ed.), Sociological Theory, San Francisco: Jossey-Bass, pp. 201-233.

Griliches, Zvi, 1979, "Issues in Assessing the Contribution of R\&D to Productivity Growth," Bell Journal of Economics, 10(Spring), 92-116.

Griliches, Zvi, 1990, "Patent Statistics as Economic Indicators: A Survey," Journal of Economic Literature, 28(4), 1661-1707.

Grossman, Gene M. and Elhanan Helpman, 1991, Innovation and Growth in the Global Economy, Cambridge Mass. MIT Press

Hannan, Michael T. and John Freeman, 1989, Organizational Ecology, Cambridge, MA: Harvard University Press.

Harhoff, D. and F. Steil, 1997, "Die ZEW-Gruendungspanels: Konzeptionelle Ueberlegungen und Analysepotential”, in Harhoff, D. (ed.), Unternehmensgruendungen - Empirische Analysen fuer die alten und neuen Bundeslaender, 7, Baden-Baden.

Hebert, R.F. and Albert N. Link, 1989) “In Search of the Meaning of Entrepreneurship,” Small Business Economics, 1(1), 39-49.

Hirschman, Albert O., 1970, Exit, Voice, and Loyalty, Cambridge: Harvard University Press.

Hofstede, G., N.G. Noorderhaven, A.R. Thurik, A.R.M. Wennekers, L. Uhlaner and R.E. Wildeman, 2002, "Culture's Role in Entrepreneurship,", in J. Ulijn and T. Brown (eds), Innovation, Entrepreneurship and Culture: The Interaction between Technology, Progress and Economic Growth,Brookfield, UK:Edward Elgar.

Jaffe, Adam B., 1989, "Real Effects of Academic Research," American Economic Review,_79(5), 957-970. 
Keilbach, M. (2000), Spatial Knowledge Spillovers and The Dynamics Of Agglomeration and Regional Growth, Physica Verlag

Lazear, Edward, 2002, “Entrepreneurship”, NBER Working Paper No. 9109

Lucas, Robert E. Jr., 1993, Making a Miracle," Econometrica, 61, 251-272.

Lucas, Robert E.,1988, “On the Mechanics of Economic Development.” Journal of Monetary Economics, 22, 339.

Organisation for Economic Co-Operation and Development (OECD), 1998, Fostering Entrepreneurship, Paris: OECD.

Porter, M., 1990, The Comparative Advantage of Nations, New York: Free Press.

Romer, Paul M., 1986, “Increasing Returns and Long-Run Growth,” Journal of Political Economy, 94(5), October, 1002-37.

Saxenien, Annalee, 1994, Regional Advantage, Cambridge, MA: Harvard University Press.

Saxenian, Annalee.,1990, "Regional Networks and the Resurgence of Silicon Valley," California Management Review, 33, 89-111.

Solow, Robert, 1956, “A Contribution to The Theory of Economic Growth”. Quarterly Journal of Economics, $70,65-94$.

Thorton, Patricia H. and Katherine H. Flynne, 2003, "Entrepreneurship, Networks and Geographies," in Zoltan J. Acs and David B. Audretsch (eds.), The International Handbook of Entrepreneurship, Dordrecht: Kluwer Academic Publishers. 


\section{Appendix}

Table 5: Regions ranked by startup intensity (startups 1989 - 1992 per population) of high-tech manufacturing industries

\begin{tabular}{|c|c|c|}
\hline Rank & Region & $\begin{array}{l}\text { High-tech manuf. } \\
\text { Startup intensity }\end{array}$ \\
\hline 1 & Tuttlingen & 0,600451 \\
\hline 2 & München & 0,582258 \\
\hline 3 & Aachen, krfr. St. & 0,517982 \\
\hline 4 & Ravensburg & 0,442391 \\
\hline 5 & Landsberg a. Lech & 0,438991 \\
\hline 6 & Starnberg & 0,404163 \\
\hline 7 & Enzkreis & 0,377389 \\
\hline 8 & Miesbach & 0,361141 \\
\hline 9 & Ebersberg & 0,358143 \\
\hline 10 & Solingen, krfr. St. & 0,355480 \\
\hline 11 & Bad Tölz-Wolfratshausen & 0,354417 \\
\hline 12 & Offenbach & 0,351651 \\
\hline 13 & Darmstadt, krfr. St. & 0,345167 \\
\hline 14 & Bodenseekreis & 0,344225 \\
\hline 15 & Speyer, krfr. Stadt & 0,343462 \\
\hline 16 & Fürstenfeldbruck & 0,339916 \\
\hline 17 & Aachen & 0,338475 \\
\hline 18 & Herford & 0,338254 \\
\hline 19 & Segeberg & 0,337696 \\
\hline 20 & Rottweil & 0,333336 \\
\hline \multicolumn{3}{|l|}{$\cdots$} \\
\hline 308 & Salzgitter, krfr. Stadt & 0,050916 \\
\hline 309 & Werra-Meissner-Kreis & 0,050894 \\
\hline 310 & Gifhorn & 0,050387 \\
\hline 311 & Neuburg-Schrobenhausen & 0,047102 \\
\hline 312 & Haßberge & 0,046271 \\
\hline 313 & Cochem-Zell & 0,046240 \\
\hline 314 & Trier-Saarburg & 0,045116 \\
\hline 315 & Hersfeld-Rotenburg & 0,045077 \\
\hline 316 & Schwalm-Eder-Kreis & 0,041891 \\
\hline 317 & Uelzen & 0,041881 \\
\hline 318 & Donnersbergkreis & 0,039844 \\
\hline 319 & Wittmund & 0,036625 \\
\hline 320 & Wolfsburg, krfr. Stadt & 0,031505 \\
\hline 321 & Aschaffenburg, krfr. St. & 0,030290 \\
\hline 322 & Kusel & 0,025294 \\
\hline 323 & Regen & 0,024462 \\
\hline 324 & Lüchow-Dannenberg & 0,019536 \\
\hline 325 & Emden, krfr. St. & 0,019303 \\
\hline 326 & Freyung-Grafenau & 0,012302 \\
\hline 327 & Kitzingen & 0,011511 \\
\hline
\end{tabular}


Table 6: Regions ranked by startup intensity (startups 1989 - 1992 per population) of ICT industries (Hardware, software, consulting, database services)

\begin{tabular}{|c|c|c|}
\hline \multirow[t]{2}{*}{ Rank } & \multirow[t]{2}{*}{ Region } & ICT Industry \\
\hline & & Startup intensity \\
\hline 1 & München & 2,519525 \\
\hline 2 & Offenbach & 2,030401 \\
\hline 3 & Starnberg & 1,835573 \\
\hline 4 & Ebersberg & 1,561137 \\
\hline 5 & Karlsruhe, krfr. St. & 1,483696 \\
\hline 6 & Freising & 1,472786 \\
\hline 7 & Darmstadt, krfr. St. & 1,423815 \\
\hline 8 & Hamburg & 1,383457 \\
\hline 9 & Hochtaunuskreis & 1,366637 \\
\hline 10 & Fürstenfeldbruck & 1,332686 \\
\hline 11 & Wiesbaden, krfr. St. & 1,319147 \\
\hline 12 & München, krfr. St. & 1,309578 \\
\hline 13 & Aachen, krfr. St. & 1,218066 \\
\hline 14 & Landsberg a. Lech & 1,214881 \\
\hline 15 & Darmstadt-Dieburg & 1,160630 \\
\hline 16 & Main-Taunus-Kreis & 1,139757 \\
\hline 17 & Frankfurt a.M., krfr. St. & 1,105130 \\
\hline 18 & Koblenz, krfr.Stadt & 1,095390 \\
\hline 19 & Rheingau-Taunus-Kreis & 1,091414 \\
\hline 20 & Offenbach a. M., krfr. St. & 1,081712 \\
\hline$\ldots$ & & $\ldots$ \\
\hline 308 & Cloppenburg & 0,241666 \\
\hline 309 & Wilhelmshaven, krfr. St. & 0,241149 \\
\hline 310 & Emsland & 0,234035 \\
\hline 311 & Lichtenfels & 0,228346 \\
\hline 312 & Wesermarsch & 0,225632 \\
\hline 313 & Trier-Saarburg & 0,225581 \\
\hline 314 & Kelheim & 0,224252 \\
\hline 315 & Bremerhaven, krfr. St. & 0,221633 \\
\hline 316 & Salzgitter, krfr. Stadt & 0,212148 \\
\hline 317 & Südwestpfalz & 0,209798 \\
\hline 318 & Freyung-Grafenau & 0,209128 \\
\hline 319 & Helmstedt & 0,206010 \\
\hline 320 & Neustadt a.d. Waldnaab & 0,202612 \\
\hline 321 & Kusel & 0,202350 \\
\hline 322 & Wittmund & 0,201439 \\
\hline 323 & Regen & 0,195700 \\
\hline 324 & Cham & 0,178735 \\
\hline 325 & Coburg & 0,177571 \\
\hline 326 & Donnersbergkreis & 0,159375 \\
\hline 327 & Cuxhaven & 0,157092 \\
\hline
\end{tabular}

